\title{
Electrochemical Etching of Zinc Oxide for Silicon Thin Film
}

\section{Solar Cell Applications}

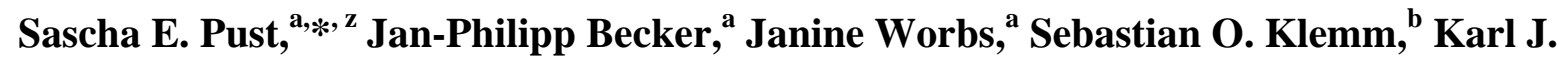

J. Mayrhofer, ${ }^{\text {b,*** }}$ and Jürgen Hüpkes ${ }^{a}$

${ }^{a}$ Forschungszentrum Jülich GmbH, IEK5 - Photovoltaik, 52425 Jülich, Germany

${ }^{b}$ Max-Planck-Institut für Eisenforschung GmbH, Max-Planck-Str. 1, 40237 Düsseldorf,

Germany

* Electrochemical Society Student Member.

** Electrochemical Society Active Member.

${ }^{\text {z }}$ Corresponding author: Dr. Sascha E. Pust, E-mail: s.pust@fz-juelich.de 


\begin{abstract}
A novel approach is presented for introducing a surface morphology with beneficial light scattering properties to sputter-deposited $\mathrm{ZnO}: \mathrm{Al}$ films, which are used as front contact in $\mathrm{Si}$ thin film photovoltaic devices. Electrochemical anodization was used to trigger local dissolution, leading to interfacial structures complementary to those commonly prepared by an etching step in diluted $\mathrm{HCl}$. By systematic variation of electrochemical etching conditions and electrolytes, the essential experimental parameters for designing the $\mathrm{ZnO}$ film surface were evaluated. The prepared films were characterized by scanning electron microscopy, four-point resistance and Hall measurements. Furthermore, electrochemical and chemical etching steps were combined to generate a diversity of different surface morphologies. The application of such films in microcrystalline Si single junction solar cells has shown promising initial results.
\end{abstract}

Keywords: photovoltaics; $\mathrm{ZnO}$ thin film; electrochemical texturing; Si thin film solar cells; etching 


\section{Manuscript}

Silicon thin film solar cells require a highly transparent front contact with low series resistance. The most commonly applied transparent conductive oxide (TCO) materials for thin film solar cells are $\mathrm{SnO}_{2}: \mathrm{In}, \mathrm{SnO}_{2}: \mathrm{F}, \mathrm{ZnO}: \mathrm{Al}$, and $\mathrm{ZnO}: \mathrm{B},{ }^{1}$ and the optimization of these TCO films has proven to be crucial for high cell efficiency. ${ }^{2}$ In superstrate configuration, the interface between the TCO and Si must provide a certain roughness for light scattering as to trap the light in the solar cell by total internal reflection within the absorber layer. For sputterdeposited $\mathrm{ZnO}: \mathrm{Al}$, this roughness is usually achieved in a chemical etching step with diluted $\mathrm{HCl}$, resulting in the 'standard Jülich' material with a favorable surface morphology for light trapping issues. ${ }^{3}$ We have recently shown that diluted HF and mixtures of $\mathrm{HF}$ and $\mathrm{HCl}$ can be utilized to structure the $\mathrm{ZnO}$ film surface more selectively, which leads to a superior solar cell performance. ${ }^{4-6}$ For less compact $\mathrm{ZnO}$ films deposited at lower substrate temperatures, mild etching agents such as $\mathrm{NH}_{4} \mathrm{Cl}$ have to be utilized to achieve sufficient roughnesses. ${ }^{7,8}$ Even though the chemical etching of single crystalline $\mathrm{ZnO}$ has been thoroughly investigated in the $1960 \mathrm{~s}^{9,10}$ on the basis of a dangling bond model, ${ }^{11}$ a significant complexity arises from the polycrystalline nature of sputter-deposited $\mathrm{ZnO}: \mathrm{Al}$ thin films. Since the etch rate is strongly dependent on the crystalline orientation, ${ }^{10}$ an inhomogeneous etching occurs on structurally heterogeneous substrates leading to complex topographies as the material corrosion proceeds. This fundamental complexity requires a constant optimization of etching conditions according to the substrate material and therefore accounts for the ongoing efforts invested in this field.

Alternatively, electrochemical processes can be utilized to deposit or modify TCO materials for solar cell applications. The electrochemical deposition of TCO films has been applied for instance in the field of organic photovoltaics ${ }^{12}$ or the generation of template-based porous structures ${ }^{13-15}$ - with the mechanistical fundamentals being well understood. ${ }^{16-19}$ The 
beneficial effect of cathodically deposited back contact $\mathrm{ZnO}$ for the light trapping properties of Si thin film solar cells has been demonstrated ${ }^{20}$ as well as the electrochemical deposition of complete CuInSe 2 thin film solar cells. ${ }^{21}$

In this paper, a new approach is presented for introducing a unique surface morphology to sputter-deposited $\mathrm{ZnO}: \mathrm{Al}$ films. Electrochemical anodization is used to trigger local dissolution of the material, leading to interfacial structures complementary to those of the standard Jülich $\mathrm{ZnO}$ prepared by simple chemical etching. The fundamental differences between chemical and electrochemical etching processes outlined in a recent work $^{22}$ therefore allow for the introduction of novel surface structures. Unique morphologies with beneficial light scattering properties are prepared by combination of electrochemical and chemical etching steps and investigated in terms of their utilizability for microcrystalline $\mathrm{Si}(\mu \mathrm{c}-\mathrm{Si}: \mathrm{H})$ single junction solar cells.

\section{Experimental}

ZnO:Al thin film deposition.- Approximately $800 \mathrm{~nm}$ thick, polycrystalline $\mathrm{ZnO}: \mathrm{Al}$ films were deposited on a cleaned $(10 \times 10) \mathrm{cm}^{2}$ glass substrate (Corning Eagle XG) using radio frequency (RF) magnetron sputtering in a vertical in-line system (VISS 300, VON ARDENNE Anlagentechnik GmbH, Dresden, Germany) from a ceramic target consisting of $\mathrm{ZnO}$ with $1 \mathrm{w} / \mathrm{w} \% \mathrm{Al}_{2} \mathrm{O}_{3}$ (Cerac Inc., Milwaukee, WI, USA). The deposition was carried out at a substrate temperature of $300^{\circ} \mathrm{C}$, a discharge power density of $2 \mathrm{~W} \mathrm{~cm}^{-2}$, and an $\mathrm{Ar}$ pressure of 0.1 Pa. Details about the process have been published elsewhere. ${ }^{23}$

Electrochemical experiments. - The electrolytes were prepared from ultrapure deionized water (Millipore, Schwalbach, Germany) and p.a. grade chemicals. Electrochemical experiments have been performed either with a $\mu$ Autolab III (Deutsche Metrohm, Filderstadt, Germany) or a Gamry Reference 600 (C3, Haar, Germany) potentiostat in a conventional 
three-electrode setup, utilizing a $\mathrm{Pt}$ wire as counter electrode and an $\mathrm{Ag}|\mathrm{AgCl}| 3 \mathrm{M} \mathrm{KCl}$ reference electrode (Deutsche Metrohm) to which all given potentials are referred. The $\mathrm{ZnO}$ :Al-covered substrate has been cut into $(5 \times 5) \mathrm{cm}^{2}$ pieces, and these have been connected as the working electrode. The temperature was kept constant at $25^{\circ} \mathrm{C}$ during all electrochemical experiments. After the electrochemical treatment, substrates were cleaned in hot, deionized water to remove salt residues originating from the electrolyte solution.

Film characterization. — Film thicknesses have been measured with a Dektak 3030 surface profiler (Veeco Instruments Ltd., Santa Barbara, CA, USA). Scanning electron microscopic (SEM) images have been recorded utilizing a Supra 55VP Smart-SEM (Carl Zeiss, Oberkochen, Germany). A four-point probe and a room temperature Keithley 926 Hall setup (Keithley Instruments, Cleveland, OH, USA) were used for electrical characterization of the films.

Solar cell preparation and characterization. - Si films were prepared by plasma enhanced chemical vapor deposition $\left(\right.$ PECVD) in a $(30 \times 30) \mathrm{cm}^{2}$ reactor. Details of the PECVD Si deposition process have been described elsewhere. ${ }^{24,25}$ The back contact consisted of sputter-deposited $\mathrm{ZnO}: \mathrm{Al}$ from the same system as the front contacts and silver deposited by thermal evaporation through a mask to determine a cell area of $(1 \times 1) \mathrm{cm}^{2}$. Solar cells were characterized with a Wacom WXS 140 S solar simulator (Wacom Electric Co., Saitama, Japan) under standard test conditions (AM1.5, $100 \mathrm{~mW} \mathrm{~cm}{ }^{-2}, 25^{\circ} \mathrm{C}$ ). The external quantum efficiency $(E Q E)$ was measured by differential spectral response (DSR) at zero bias. 


\section{Results and Discussion}

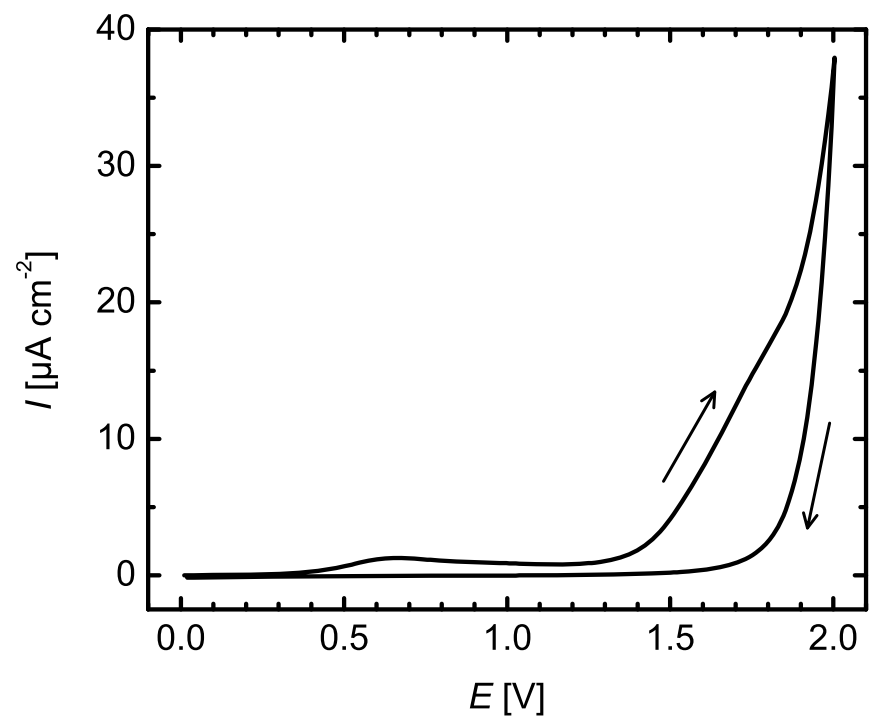

Figure 1. $\mathrm{CV}\left(50 \mathrm{mV} \mathrm{s}^{-1}\right)$ of a sputter-deposited $\mathrm{ZnO}$ : $\mathrm{Al}$ thin film in $0.1 \mathrm{M} \mathrm{K}_{2} \mathrm{SO}_{4}$ (potential vs $\mathrm{Ag}|\mathrm{AgCl}| 3 \mathrm{M} \mathrm{KCl})$.

Anodic dissolution of $\mathrm{ZnO}: A l$ - - In acidic ${ }^{26,27}$ as well as in alkaline ${ }^{28,29}$ media, the chemically induced conversion of $\mathrm{ZnO}$ into soluble complexes proceeds at quite significant reaction rates due to the amphoteric character of $\mathrm{Zn}$. At $\mathrm{pH}$ values around 8-10 and without contribution of other ions, however, $\mathrm{ZnO}$ is thermodynamically stable. ${ }^{30,31}$ Only negligible dissolution rates are observed under neutral or slightly acidic conditions due to either slow kinetics ${ }^{32}$ or transport limitations of the etching agent (e.g. protons). ${ }^{33}$ Hence, to separate electrochemically triggered dissolution from purely chemical effects, initial investigations have been performed in $\mathrm{KCl}$ or $\mathrm{K}_{2} \mathrm{SO}_{4}$ with a solution $\mathrm{pH}$ close to 7 . Tests have shown that the surface texture of the RF-sputtered $\mathrm{ZnO}: \mathrm{Al}$ is not changed, even after immersion into these electrolytes for several hours. The cyclic voltammogram (CV) in Fig. 1 shows a potential window of up to approximately $+1.3 \mathrm{~V}$ vs $\mathrm{Ag}|\mathrm{AgCl}| 3 \mathrm{M} \mathrm{KCl}$ where the $\mathrm{ZnO}: \mathrm{Al}$ is electrochemically stable. At higher anodic potentials dissolution of $\mathrm{ZnO}$ sets in, indicated by a significant increase in current density up to $\sim 40 \mu \mathrm{A} \mathrm{cm}{ }^{-2}$. The electrochemical $\mathrm{ZnO}$ 
dissolution can occur via two competing reactions, namely the direct lattice decomposition $(\text { Eq. } 1)^{34}$

$$
2 \mathrm{ZnO} \rightarrow 2 \mathrm{Zn}^{2+}+\mathrm{O}_{2}+4 \mathrm{e}^{-}
$$

or the oxygen evolution reaction (OER, Eq. 2) with a subsequent chemical dissolution of the $\mathrm{ZnO}$ film due to a shift in the surface pH (Eq. 3).

$$
\begin{gathered}
2 \mathrm{H}_{2} \mathrm{O} \rightarrow 4 \mathrm{H}^{+}+\mathrm{O}_{2}+4 \mathrm{e}^{-} \\
2 \mathrm{ZnO}+4 \mathrm{H}^{+} \rightarrow 2[\mathrm{ZnOH}]^{+}+2 \mathrm{H}^{+} \rightarrow 2 \mathrm{Zn}^{2+}+2 \mathrm{H}_{2} \mathrm{O}
\end{gathered}
$$

The reader is referred to Ref. 22 for a detailed discussion of the possible dissolution mechanisms derived from galvanostatic experiments with a microelectrochemical scanning flow cell.

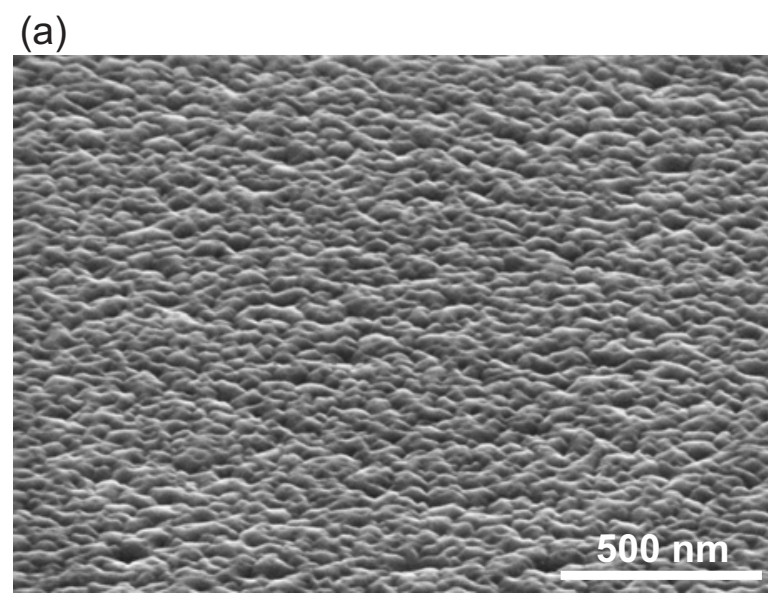

(b)

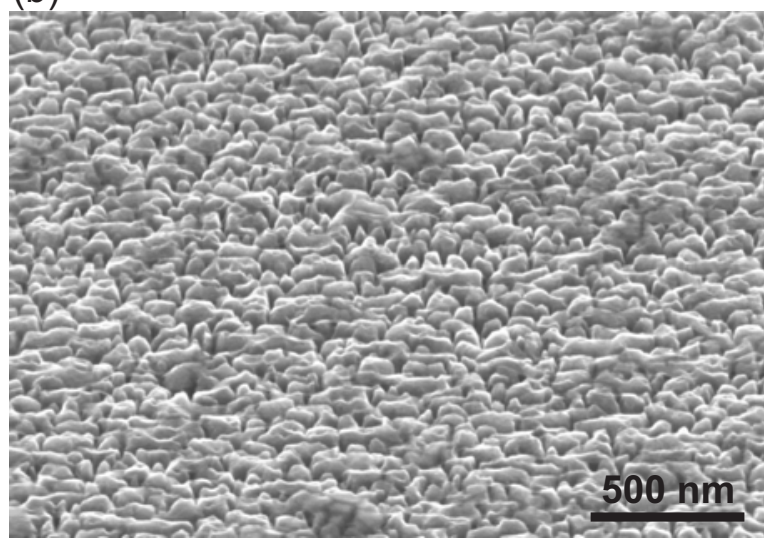

Figure 2. SEM micrographs of a $\mathrm{ZnO}: \mathrm{Al}$ thin film (a) in the as-deposited state; (b) after electrochemical treatment at $+2 \mathrm{~V}$ in $0.1 \mathrm{M} \mathrm{KCl}$ for $13 \mathrm{~min}$. 
Independent of the corrosion mechanism, the anodic $\mathrm{ZnO}$ dissolution leads to a surface morphology where the grain boundaries deepen in the course of the experiment (Fig. 2). Obviously, both possible interfacial reactions (Eqs. 1 and 2) are distinctly limited to the grain boundaries of the polycrystalline material with a stunning degree of selectivity, and do not attack the $\mathrm{ZnO}$ grains. In case of RF-sputtered $\mathrm{ZnO}$ films, the crystallites preferentially grow toward the [0001] direction, which means that the grains are highly c-axis oriented after the deposition. ${ }^{35}$ This has also been observed for the $\mathrm{ZnO}$ films used in this study. ${ }^{36}$ Hence, the dissolution rate of the c-axis oriented grains under anodic polarization seems to be negligibly low, especially when compared to the dissolution rate at the grain boundaries. Surface profilometric measurements support that observation, as no integral thickness changes are observed after the electrochemical treatment. Thus, the resulting structure differs remarkably from the crater-like structures of the standard Jülich $\mathrm{ZnO}$, which is etched in diluted $\mathrm{HCl}$ only. ${ }^{3,4}$ Even though the grain boundaries are also the origin of crater growth when etching with $\mathrm{HCl}$, in particular the triple points of grain boundaries, ${ }^{37}$ the c-axis grains are always etched as well in this case. In contrast to electrochemical etching, the chemical etching is dominated by the diffusion of protons towards the surface. ${ }^{22}$ Consequently the resulting craters can extend even over several grains.

In a chronoamperometric experiment at a potential of $+2 \mathrm{~V}$ vs $\mathrm{Ag}|\mathrm{AgCl}| 3 \mathrm{M} \mathrm{KCl}$, the current flow is quite stable over a period of more than $10 \mathrm{~min}$, and the dissolution rates are well-controllable. The charge $Q$ that is forced through the $\mathrm{ZnO}$ :Al thin film increases almost linearly with treatment duration, and $Q$ is directly related to the changes in sheet resistance of the film with time compared to the as-deposited state. This is exemplified in Fig. 3a for a treatment at $+2 \mathrm{~V}$ in $0.1 \mathrm{M} \mathrm{KCl}$. Similar trends have been observed for solutions of $\mathrm{K}_{2} \mathrm{SO}_{4}$ and $\mathrm{KNO}_{3}$, albeit the linear dependency of sheet resistance and $Q$ with etch duration exhibit remarkably different slopes (Fig. 3b). It has been previously mentioned that chemical etching 
does not occur at significant rates in the electrolytes used. Online detection of zinc dissolution performed in another study ${ }^{22}$ has shown that the electrochemical dissolution efficiency of $\mathrm{ZnO}: \mathrm{Al}$ is approximately $90 \%$. This implies that almost the whole applied charge results in the liberation of zinc ions from the surface. Due to this relationship, the amount of material removed by potentiostatic techniques is a function of the applied charge and therefore independent of the electrolyte. The large differences observed in Fig. $3 \mathrm{~b}$ are hence not a consequence of an increased etch rate in $\mathrm{K}_{2} \mathrm{SO}_{4}$, but display an increased impact of the material loss on the sheet resistance.

(a)

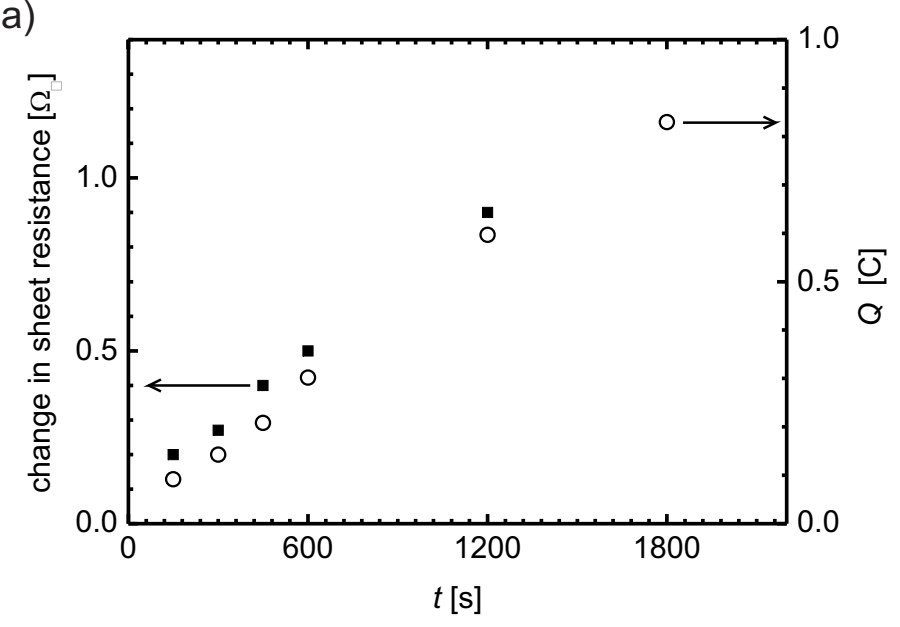

(b)

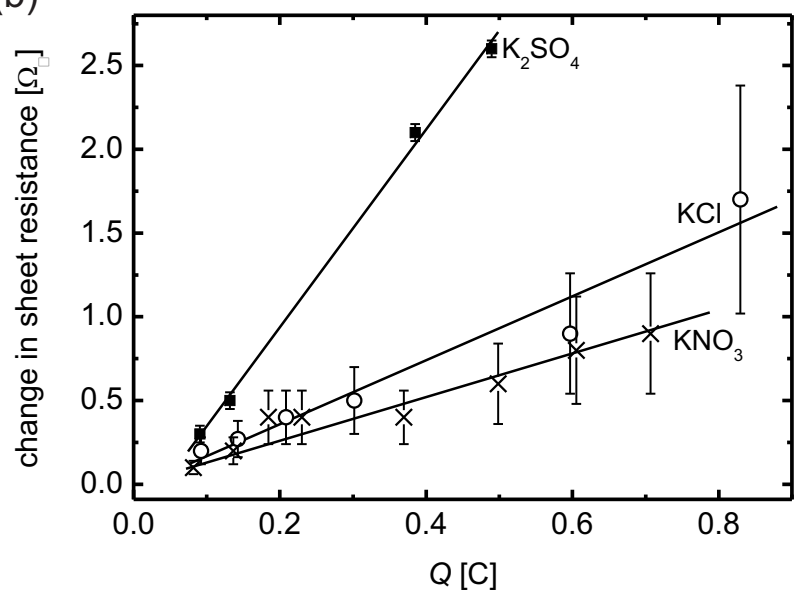

Figure 3. (a) Changes in sheet resistance (solid squares) and charge $Q$ (open circles) determined from chronoamperometric data as a function of the electrochemical treatment duration $t$ in $0.1 \mathrm{M} \mathrm{KCl}$ at $+2 \mathrm{~V}$. (b) Relation between changes in sheet resistance and charge $Q$ for electrochemical treatments at $+2 \mathrm{~V}$ in $0.1 \mathrm{M} \mathrm{K}_{2} \mathrm{SO}_{4}$ (solid squares), $0.1 \mathrm{M} \mathrm{KCl}$ (open circles), and $0.1 \mathrm{M} \mathrm{KNO}_{3}$ (crosses). 
In the case of dissolution proceeding in grooves or pits of growing depth, local saturation of the solution and the resulting inhibition of the dissolution reaction become important. A high aspect ratio between width and depth additionally limits transport processes, which implies that a significant enrichment of dissolved zinc occurs after the electrochemical etching formed sufficiently deep features. Sulfate ions in particular are known to strongly interfere with zinc precipitation as was shown on the example of surface film dissolution on zinc. ${ }^{38}$ They are therefore assumed to promote the growth of the etch pits in depth which is supported by higher current densities at equal bias potentials.

It is, however, noteworthy that the composition of the electrolyte does not have a significant influence on the surface morphology after the purely electrochemical treatment. As long as the $\mathrm{pH}$ is kept in the neutral range, the resulting structures are very similar in all cases, which additionally suggests that the electrolyte composition requires local saturation (pits of sufficient depth) to become significant, therefore leaving the top layers almost unaffected. If the chronoamperometric experiment is extended up to half an hour and more (depending on the utilized electrolyte), the current density drops almost to zero. This is tantamount to an undesired electrical breakdown of the film when the grain boundary pits reach the glass substrate, being accompanied by a total loss of lateral conductivity and a significant increase in sheet resistance. This effect is strongly accelerated in sulfate containing media being further evidence of a quicker progression of the respective grooves into the surface. In general, though, the easily determinable sheet resistance can be seen as a suitable measure for monitoring the electrochemical treatment of the thin film due to the linear dependencies demonstrated in Fig. 3.

Combination of etching steps. - The unique locally limited effect from the electrochemical anodization can now be combined with a subsequent traditional chemical 
etching step in order to tune the surface structures with respect to their light scattering ability. The electrochemical pretreatment widens the grain boundaries and generates a significant number of new sites for the attack by acidic etching. By changing the etch time in $\mathrm{HCl}$ after anodization in $\mathrm{K}_{2} \mathrm{SO}_{4}$, the morphology gradually shifts from extremely small craters to sizes being closer to those after a purely chemical etch as for the standard Jülich $\mathrm{ZnO}$ (Fig. 4). Since the etch pits are obviously not only generated at some peculiar grain boundaries as in the purely chemical treatment, the density of craters is higher, their diameter is lower, and the shapes are more regular than the ones of the standard Jülich $\mathrm{ZnO}$.

(a)

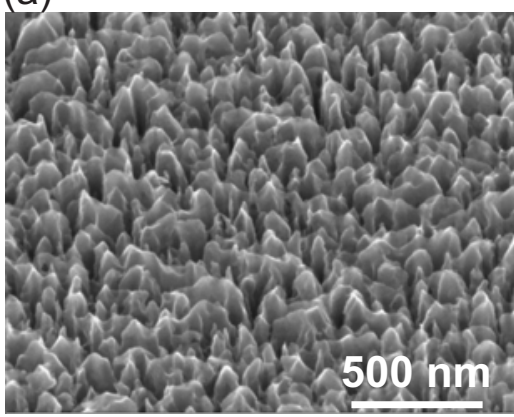

(d)

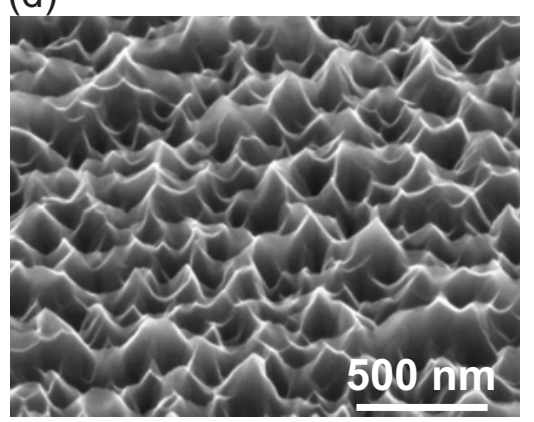

(b)

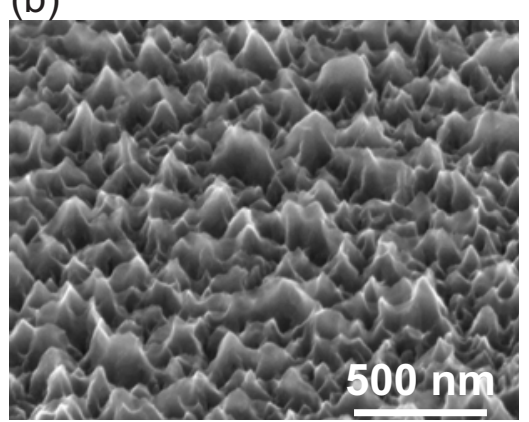

(e)

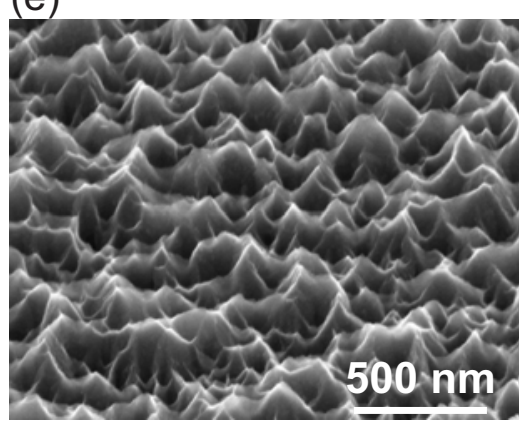

(c)

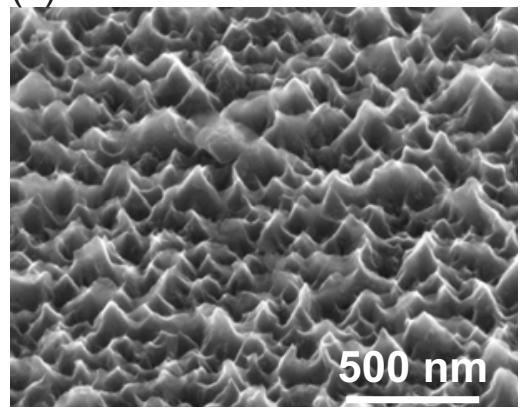

(f)

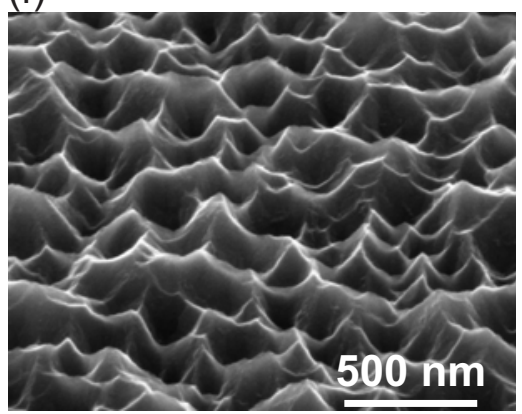

Figure 4. SEM micrographs of $\mathrm{ZnO}$ : $\mathrm{Al}$ thin films after biasing at $+2 \mathrm{~V}$ for $10 \mathrm{~min}$ in $0.1 \mathrm{M} \mathrm{K}_{2} \mathrm{SO}_{4}$ and subsequent etching in $0.5 \mathrm{w} / \mathrm{w} \% \mathrm{HCl}$ for (a) a short dip, (b) $5 \mathrm{~s}$, (c) $10 \mathrm{~s}$, (d) $20 \mathrm{~s}$, (e) $30 \mathrm{~s}$, (f) $40 \mathrm{~s}$.

While the composition of the electrolyte is almost not affecting the surface morphology of the substrate after the electrochemical treatment in neutral or slightly alkaline $\mathrm{pH}$ conditions, this is not true for the twice-etched $\mathrm{ZnO}$ thin films. In contrast to anodization in $\mathrm{K}_{2} \mathrm{SO}_{4}$, the influence of the electrochemical pretreatment in $\mathrm{KCl}$ as electrolyte on the surface 
morphology seems to be less pronounced, and the resulting structures are markedly different (Fig. 5). Initially, e.g., after a short dip in $\mathrm{HCl}$ (Fig. 5a), the accentuation of the grain boundaries is still visible in terms of an increased density of craters. This however vanishes almost completely after prolonged etching (Fig. 5b-d), so that after 30 or $40 \mathrm{~s}$ of etching (Fig. 5e-f) the morphology is similar to that of a standard Jülich $\mathrm{ZnO}$ substrate. Furthermore, the increase in crater diameter is not as gradual as observed after anodization in $\mathrm{K}_{2} \mathrm{SO}_{4}$ (Fig. 4), although it is still visible.

(a)

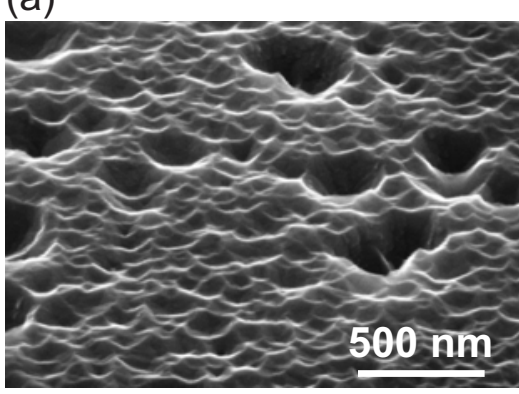

(d)

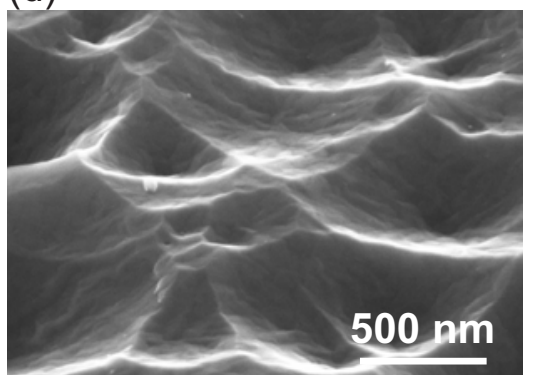

(b)

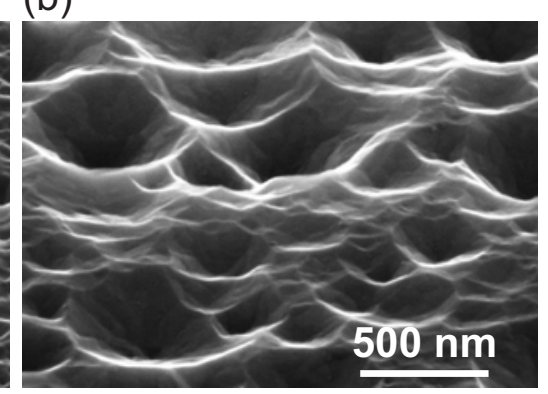

(e)

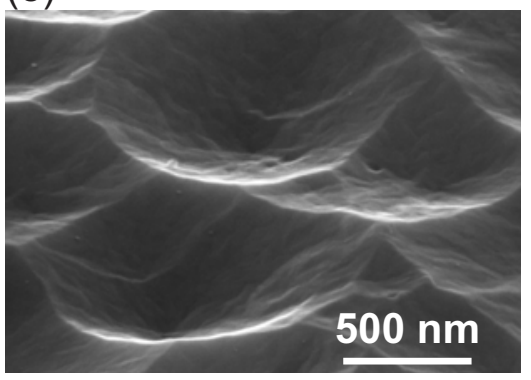

(c)

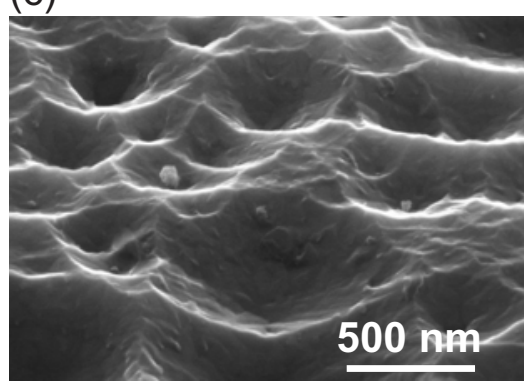

(f)

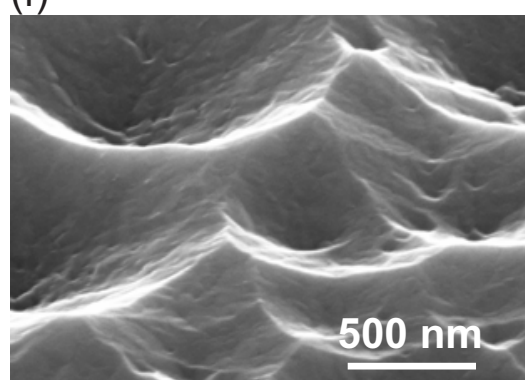

Figure 5. SEM micrographs of $\mathrm{ZnO}: \mathrm{Al}$ thin films after biasing at $+2 \mathrm{~V}$ for $5 \min$ in $0.1 \mathrm{M} \mathrm{KCl}$ and subsequent etching in $0.5 \mathrm{w} / \mathrm{w} \% \mathrm{HCl}$ for (a) a short dip, (b) $5 \mathrm{~s}$, (c) $10 \mathrm{~s}$, (d) $20 \mathrm{~s}$, (e) $30 \mathrm{~s}$, (f) $40 \mathrm{~s}$.

The aforementioned effects of sulfate ions on the $\mathrm{ZnO}: \mathrm{Al}$ thin film are considered as reasons for the observed difference. Obviously, these effects become especially evident after the etch step in $\mathrm{HCl}$. This is in agreement with the confinement of the structural differences to the inside of the etched grain boundaries after the electrochemical treatment, being revealed by the proceeding chemical dissolution. 

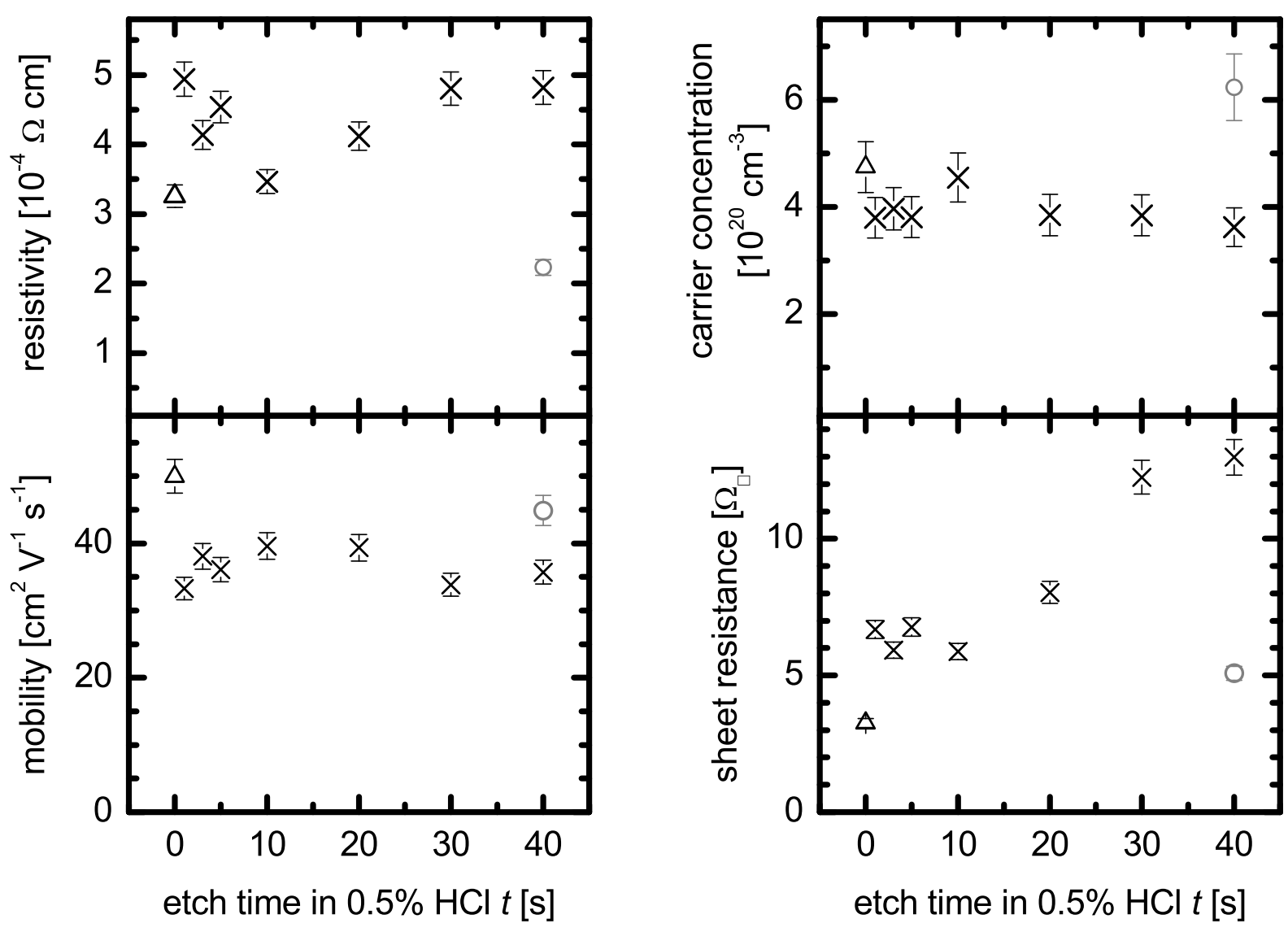

Figure 6. Electrical properties of twice-etched, RF-sputtered $\mathrm{ZnO}$ :Al thin films derived from Hall measurements. All films were firstly biased at $+2 \mathrm{~V}$ for $10 \mathrm{~min}$ in $0.1 \mathrm{M} \mathrm{K}_{2} \mathrm{SO}_{4}$ and secondly etched in $0.5 \mathrm{w} / \mathrm{w} \% \mathrm{HCl}$ for different etch times. The values at $0 \mathrm{~s}$ etch time (open triangles) show the properties of the untreated, as-deposited film. The standard Jülich $\mathrm{ZnO}$ reference $(\mathrm{ZnO}: \mathrm{Al}$ etched in $0.5 \mathrm{w} / \mathrm{w} \%$ $\mathrm{HCl}$ for $40 \mathrm{~s}$ without electrochemical pretreatment) is shown in gray (open circles). Relative errors of $\pm 10 \%$ for the carrier concentration and $\pm 5 \%$ for the mobility, sheet resistance, and resistivity are estimated and shown as error bars.

Although the surface structure obtained by pretreatment is clearly depending on the electrolyte, the electrical properties of the textured $\mathrm{ZnO}: \mathrm{Al}$ thin films are not significantly different. Hall measurements of the resistivity, carrier concentration, mobility, and sheet resistance are presented in Fig. 6 as a function of etch time of $\mathrm{K}_{2} \mathrm{SO}_{4}$-pretreated samples in $0.5 \mathrm{w} / \mathrm{w} \% \mathrm{HCl}$. The sheet resistance increases from $(3.3 \pm 0.2) \Omega_{\square}$ in the as-deposited state 
(shown at $0 \mathrm{~s}$ ) to $(13.0 \pm 0.6) \Omega_{\square}$ after electrochemical pretreatment and $40 \mathrm{~s}$ of etching in diluted $\mathrm{HCl}$. The latter value is also significantly higher than those of the standard Jülich $\mathrm{ZnO}$ films that usually lie well below $10 \Omega_{\square}\left((5.1 \pm 0.3) \Omega_{\square}\right.$ for the reference substrate in this measurement series (shown in gray)). A very similar trend is observed for the resistivity. The increase for the twice-etched substrates compared to the reference substrate indicates that the chemical etching step is accelerated by the electrochemical pretreatment. This supports the assumption that new points of attack for the etchant are generated by the anodization step. This observation, however, illustrates the necessity for a careful consideration between improved optical properties, originating from more optimized surface morphologies, and a lowered conductivity, which is of course not desirable for an application of these films in solar cells.

The mobility and carrier concentration are not influenced significantly by the electrochemical treatment; the values remain almost constant within the measurement uncertainty. Interestingly, the carrier concentration in the standard Jülich $\mathrm{ZnO}$ reference film etched for $40 \mathrm{~s}$ in $\mathrm{HCl}$ without electrochemical pretreatment is approximately $2.5 \times 10^{20} \mathrm{~cm}^{-3}$ higher than that after anodization and etching in $\mathrm{HCl}$ for $40 \mathrm{~s}$. However, this aspect should not be overinterpreted as the error in film thickness measurements has to be considered for the determination of the carrier concentration as well: in the van der Pauw method ${ }^{39}$ utilized for these measurements, the carrier concentration is inversely proportional to the film thickness. This error clearly dominates the total measurement error on rough films. The same is true for the resistivity which is directly proportional to the film thickness.

The combination of electrochemical treatment in different electrolytes and chemical etching opens up new ways to change the electrical and optical properties of $\mathrm{ZnO}$ thin films. This substantially extends the already high number of accessible structures that could be obtained by varying sputtering conditions together with purely chemical etching, as reported by Berginski et al. ${ }^{23}$ By selectively tuning the crater size and (ir-)regularity, a material may 
thus be optimized for the needs of the Si absorber that is being deposited on top of it. This could, for example, allow a better adaption of the light scattering in different regions of the spectrum of light to single junction and tandem solar cells. Furthermore, the high aspect ratios of the grain boundaries will also affect the $\mathrm{Si}$ deposition process and the TCO/p-Si contact.

$\mu c-S i: H$ solar cell results. - To check the quality of the twice-etched $\mathrm{ZnO}$ films in terms of light scattering ability and electrical contact to the p-doped layer of the Si absorber, $(1 \times 1)$ $\mathrm{cm}^{2} \mu \mathrm{c}-\mathrm{Si}: \mathrm{H}$ single junction thin film solar cells have been prepared. A $\sim 1 \mu \mathrm{m}$ thick absorber with a $\mathrm{ZnO} / \mathrm{Ag}$ back contact was used as layer system, utilizing the twice-etched $\mathrm{ZnO}$ :Al film as front contact. To evaluate the influence of the electrochemical pretreatment and the crater diameter, solar cell deposition was carried out on all the films with $\mathrm{KCl}$ pretreatment shown in Fig. 5 and, in addition to that, on a standard Jülich $\mathrm{ZnO}$ reference substrate etched in 0.5 $\mathrm{w} / \mathrm{w} \% \mathrm{HCl}$ for $50 \mathrm{~s}$ only. The characteristic parameters of these solar cells, namely the initial efficiency $\eta_{\text {init, }}$, fill factor $F F$, open circuit voltage $V_{\text {oc }}$, and short circuit current density $J_{\text {sc }}$, are shown in Fig. 7 as a function of the etch time in $0.5 \mathrm{w} / \mathrm{w} \% \mathrm{HCl}$. Please note that, other than in Fig. 6, the data set at $0 \mathrm{~s}$ etch time does not represent the as-deposited $\mathrm{ZnO}$ :Al thin film, but the film after anodization without any etch step in $\mathrm{HCl}$. The results of the best solar cells for each time step are collected in Table I.

Table I. I/V characteristics of best solar cells $\left(1 \mathrm{~cm}^{2}\right)$ on twice-etched, RF-sputtered ZnO:Al films with pretreatment for $5 \mathrm{~min}$ at $+2 \mathrm{~V}$ in $0.1 \mathrm{M} \mathrm{KCl}$.

\begin{tabular}{ccccc}
$\begin{array}{c}\text { Etch duration in } 0.5 \mathrm{w} / \mathrm{w} \% \mathrm{HCl} \\
\text { after pretreatment }(\mathrm{s})\end{array}$ & $\eta_{\text {init }}(\%)$ & $F F(\%)$ & $V_{\text {oc }}(\mathrm{mV})$ & $J_{\text {sc }}\left(\mathrm{mA} \mathrm{cm}^{-2}\right)$ \\
\hline 0 & 5.54 & 67.0 & 511 & 16.18 \\
2 & 6.49 & 72.6 & 512 & 17.48 \\
5 & 7.19 & 70.9 & 509 & 19.92 \\
10 & 7.25 & 66.9 & 498 & 21.74 \\
20 & 7.93 & 69.3 & 514 & 22.23 \\
30 & 8.08 & 70.5 & 517 & 22.16 \\
40 & 8.13 & 68.9 & 506 & 23.30 \\
50 (reference; no pretreatment) & 7.83 & 67.6 & 505 & 22.93
\end{tabular}




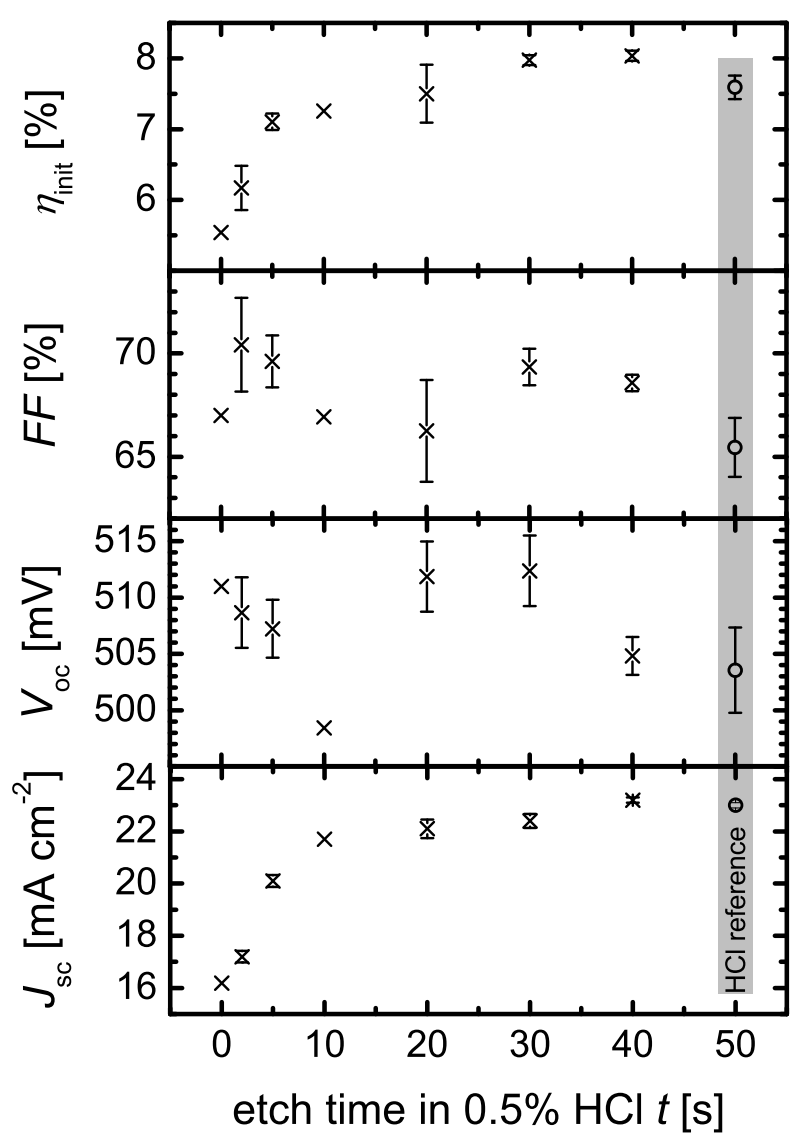

Figure 7. Initial efficiency $\eta_{\text {init }}$, fill factor $F F$, open circuit voltage $V_{\text {oc }}$, and short circuit current density $J_{\mathrm{sc}}$ of $\mu \mathrm{c}-\mathrm{Si}: \mathrm{H}$ solar cells on twice-etched, RF-sputtered $\mathrm{ZnO}$ :Al films. All films were firstly biased at $+2 \mathrm{~V}$ for $5 \mathrm{~min}$ in $0.1 \mathrm{M} \mathrm{KCl}$ and secondly etched in $0.5 \mathrm{w} / \mathrm{w} \% \mathrm{HCl}$ for different etch times before $\mathrm{Si}$ deposition. The data set marked as $\mathrm{HCl}$ reference (shown in gray, open circles) is a solar cell with standard Jülich $\mathrm{ZnO}: \mathrm{Al}$ etched in $0.5 \mathrm{w} / \mathrm{w} \% \mathrm{HCl}$ for $50 \mathrm{~s}$ without electrochemical pretreatment.

The most obvious outcome of this experiment is the fact that $\eta_{\text {init }}$ as well as $J_{\text {sc }}$ increase as a function of the etch time in $\mathrm{HCl}$. As the craters grow in diameter and in depth, the light scattering ability of the $\mathrm{ZnO}$ :Al thin film is enhanced. This increases the probability of light absorption in the Si absorber and thus the current density due to a prolongation of the optical path length and an improved light trapping. ${ }^{1}$ The highest current density values reached are in the range of $(23.2 \pm 0.1) \mathrm{mA} \mathrm{cm}{ }^{-2}$ for the twice-etched films. This corresponds well to $J_{\mathrm{sc}}$ of the standard Jülich $\mathrm{ZnO}$ reference film, but does not exceed it. This is consistent with the 
observation that the morphology of the film (Fig. 5f) is very similar to that of the reference with crater diameters in the range of a few $100 \mathrm{~nm}$.

The same trend can also be visualized as a function of the wavelength in DSR measurements (Fig. 8). As expected, non-optimized $\mathrm{ZnO}$ film morphologies render lower EQE values than the reference film over the whole spectral range (Fig. 8a, gray line). Especially for the very short etch times in $\mathrm{HCl}$ (hence an almost smooth film surface), optical interferences at wavelengths $\lambda$ of $\sim 500 \mathrm{~nm}$ and above are observed due to Fabry-Pérot oscillations. These originate from reflection at the front and the back side of the $\mathrm{ZnO}$ :Al front contact (for $\lambda<600 \mathrm{~nm}$ ) or Si (for $\lambda>600 \mathrm{~nm}$ ). In agreement with the $J_{\mathrm{sc}}$ data (Fig. 7), the $E Q E$ values of the solar cells on the twice-etched $\mathrm{ZnO}$ reach the level of the standard Jülich $\mathrm{ZnO}$ reference (Fig. 8a, cf. gray vs dotted line), but do not exceed it. This indicates that the surface morphology of the electrochemically pretreated substrates is not more suitable than that of the reference film for this specific cell design in terms of light trapping issues, and electrochemically introduced craters possess slightly too low diameters for a more efficient overall light scattering. Only a closer look at the short wavelength range from 370 to $550 \mathrm{~nm}$ (Fig. 8b) implicates a gain for the film etched for $40 \mathrm{~s}$ in $\mathrm{HCl}$ after electrochemical pretreatment (dotted line) compared to the reference (gray line). Such an effect could be explained by craters with a diameter slightly below the ones of the reference and a stronger effect on the short wavelengths. Its significance however still needs to be verified. 


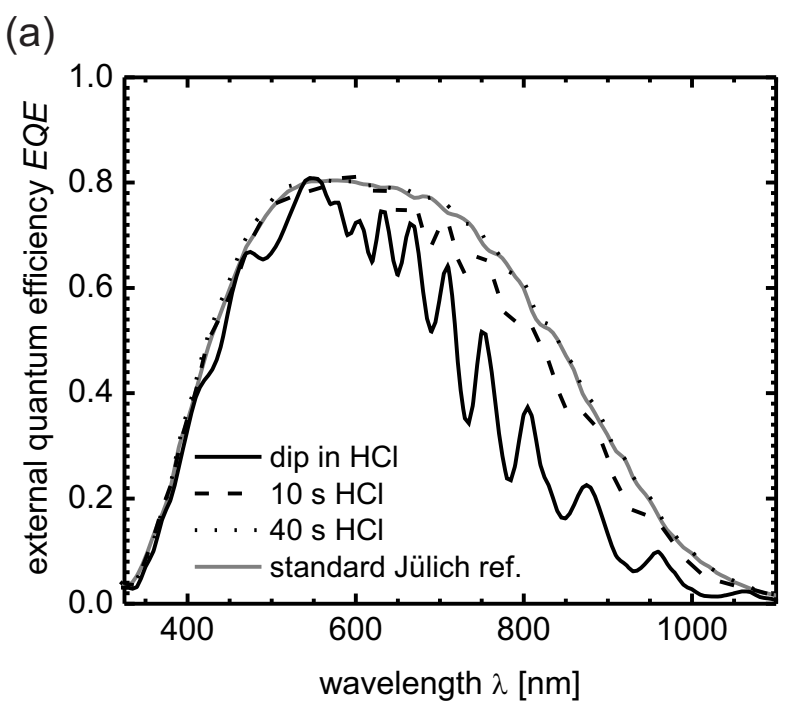

(b)

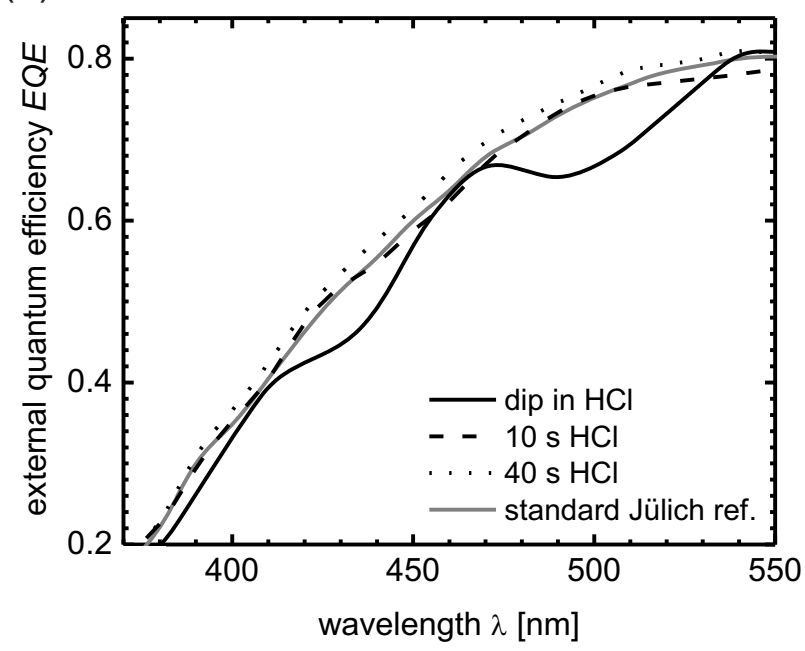

Figure 8. External quantum efficiencies of $\mu \mathrm{c}-\mathrm{Si}: \mathrm{H}$ solar cells on twice-etched, RF-sputtered $\mathrm{ZnO}: \mathrm{Al}$ films. All films were firstly biased at $+2 \mathrm{~V}$ for $5 \mathrm{~min}$ in $0.1 \mathrm{M} \mathrm{KCl}$ and secondly etched in $0.5 \mathrm{w} / \mathrm{w} \%$ $\mathrm{HCl}$ for a short dip (solid), $10 \mathrm{~s}$ (dashed), and $40 \mathrm{~s}$ (dotted), respectively, before Si deposition. The standard Jülich $\mathrm{ZnO}$ reference (solar cell with $\mathrm{ZnO}: \mathrm{Al}$ etched in $0.5 \mathrm{w} / \mathrm{w} \% \mathrm{HCl}$ for $50 \mathrm{~s}$ without electrochemical pretreatment) is shown in gray.

$\eta_{\text {init }}$ shows the same tendency as $J_{\text {sc }}$. The maximum value of $(8.0 \pm 0.1) \%$ for the film etched for $40 \mathrm{~s}$ in $0.5 \mathrm{w} / \mathrm{w} \% \mathrm{HCl}$ after electrochemical pretreatment (Fig. 7) is however approximately $0.4 \%$ higher than the standard Jülich $\mathrm{ZnO}$ reference solar cell. This surprising effect cannot be explained by an improved light trapping, as this would have an effect on $J_{\mathrm{sc}}$ 
as well. It seems that the enhanced cell efficiency mainly originates from an improved $F F$ and $V_{\text {oc }}$, despite the significant scatter of the data of these two parameters. Especially $V_{\text {oc }}$ is up to $10 \mathrm{mV}$ higher for the pretreated samples compared to the standard Jülich $\mathrm{ZnO}$ film. This could be an indication for an improved electrical matching in terms of work function between the $\mathrm{ZnO}: \mathrm{Al}$ front contact and the $\mathrm{Si}$ absorber. A different growth of $\mathrm{Si}$ due to the different morphology or surface chemistry might also contribute to this improvement. One has to note that, in this specific cell deposition, comparably low overall $V_{\text {oc }}$ values are an indication for deviations from the standard Si deposition process. Since all solar cells have been prepared in one co-deposition step, however, the relative comparability of the values is valid.

\section{Table II. I/V characteristics of best solar cells $\left(1 \mathrm{~cm}^{2}\right)$ on twice-etched, RF-sputtered ZnO:Al films with pretreatment for $5 \mathrm{~min}$ at $+2 \mathrm{~V}$ in $0.1 \mathrm{M} \mathrm{K}_{2} \mathrm{SO}_{4}$.}

\begin{tabular}{ccccc}
$\begin{array}{c}\text { Etch duration in } 0.5 \mathrm{w} / \mathrm{w} \% \mathrm{HCl} \\
\text { after pretreatment }(\mathrm{s})\end{array}$ & $\eta_{\text {init }}(\%)$ & $F F(\%)$ & $V_{\text {oc }}(\mathrm{mV})$ & $J_{\mathrm{sc}}\left(\mathrm{mA} \mathrm{cm}{ }^{-2}\right)$ \\
\hline 10 & 7.23 & 68.9 & 540 & 19.45 \\
30 & 8.35 & 73.0 & 543 & 21.09 \\
50 (reference; no pretreatment) & 8.41 & 73.2 & 526 & 22.90
\end{tabular}

The best solar cell results for twice-etched $\mathrm{ZnO}: \mathrm{Al}$ films electrochemically pretreated in $\mathrm{K}_{2} \mathrm{SO}_{4}$ (as seen in Fig. 4) are summarized in Table II. While the electrolyte has got a major influence on the film morphology (Fig. 4), the single junction solar cell performance is quite similar. Overall, the observations of the results of the previously shown solar cells with $\mathrm{KCl}$ pretreatment are fully confirmed in the solar cell deposition on $\mathrm{K}_{2} \mathrm{SO}_{4}$-pretreated films: (i) $J_{\mathrm{sc}}$ is maximum for the solar cell on the standard Jülich $\mathrm{ZnO}$ reference film without electrochemical pretreatment; (ii) $\eta_{\text {init }}$ can be brought close to the reference by the anodization process with a maximum value of $8.35 \%$ for a solar cell on a twice-etched film; (iii) $V_{\mathrm{oc}}$ is more than $10 \mathrm{mV}$ higher for the solar cells on the twice-etched films; (iv) no clear trend is observed for FF. 


\section{Conclusions and Outlook}

In summary, we have presented a novel approach to change the surface morphology of RF-sputtered ZnO:Al thin films by means of an anodic electrochemical treatment. The resulting interfacial reaction is distinctly limited to the grain boundaries of the thin film, leading to unique surface structures that cannot be achieved by any other solution-based technique. The combination of this electrochemical approach with chemical etching in diluted $\mathrm{HCl}$ allowed us to tune the surface morphology of the $\mathrm{ZnO}$ :Al thin films such that it will be beneficial for an application as a front contact in Si thin film solar cells. Additionally, the electrochemical treatment influences the electrical properties of the $\mathrm{ZnO}$ for subsequent $\mathrm{Si}$ deposition, enabling a more selective adjustment of the material.

The application of such films in $\mu \mathrm{c}-\mathrm{Si}: \mathrm{H}$ single junction solar cells has proven their utilizability for Si thin film photovoltaic applications. It was observed that the tuning of the $\mathrm{ZnO}$ film surface morphology can contribute to an improved light trapping in the solar cell. The generation of optimum structures, though, strongly depends on the experimental parameters of the surface treatment (electrochemical as well as chemical) and on the physical properties of the $\mathrm{ZnO}$ film.

While the results reported in this paper are only the initial step towards an optimization of the etching procedure, the potential of the electrochemical treatment for an improvement of sputter-deposited $\mathrm{ZnO}$ front contact layers has been clearly demonstrated. Further work has to be done to understand and systemize the influence of the electrochemical treatment on the $\mathrm{ZnO}$ thin film and on the resulting solar cells. Especially for films with excellent electrical and optical properties derived from slightly different deposition conditions, which cannot be etched easily in the established processes, the electrochemical treatment might be the key for an application as front contacts in Si thin film solar cells. This might ultimately lead to an increased overall solar cell performance. 


\section{Acknowledgments}

The authors thank Carsten Grates, Joachim Kirchhoff, and Etienne Moulin for assistance in solar cell preparation and characterization as well as Karsten Bittkau, Aad Gordijn, and Uwe Rau (all Forschungszentrum Jülich $\mathrm{GmbH}$ ) for fruitful discussions. SEM images have been recorded by Hans Peter Bochem (PGI-8-PT, Forschungszentrum Jülich GmbH). Financial support by the Deutsche Forschungsgemeinschaft (DFG, grant PU 447/1-1), the German Federal Environment Ministry (BMU, grant 0327693A), and the Dortmunder Oberflächencentrum is gratefully acknowledged. 


\section{References}

1. J. Hüpkes, J. Müller, and B. Rech, in Transparent Conductive Zinc Oxide: Basics and Applications in Thin Film Solar Cells, K. Ellmer, A. Klein, and B. Rech, Editors, p. 362, Springer, Berlin, Germany (2008).

2. B. Rech and H. Wagner, Appl. Phys. A, 69, 155 (1999).

3. M. Kubon, E. Boehmer, F. Siebke, B. Rech, C. Beneking, and H. Wagner, Sol. Energy Mater. Sol. Cells, 41-42, 485 (1996).

4. J. I. Owen, J. Hüpkes, H. Zhu, E. Bunte, and S. E. Pust, Phys. Status Solidi A, 208, 109 (2011).

5. J. I. Owen, J. Hüpkes, E. Bunte, S. E. Pust, and A. Gordijn, in Proceedings of the 25th European Photovoltaic Solar Energy Conference, Valencia, Spain, p. 2951, WIP, Munich, Germany (2010).

6. J. Hüpkes, J. I. Owen, E. Bunte, H. Zhu, S. E. Pust, J. Worbs, and G. Jost, in Proceedings of the 25th European Photovoltaic Solar Energy Conference, Valencia, Spain, p. 3224, WIP, Munich, Germany (2010).

7. J. W. Kwon and E. S. Kim, J. Microelectromech. Syst., 14, 603 (2005).

8. S. Fernández, A. Bollero, F. B. Naranjo, O. de Abril, J. Cárabe, and J. J. Gandía, Proceedings of the 25th European Photovoltaic Solar Energy Conference, Valencia, Spain, p. 2991, WIP, Munich, Germany (2010).

9. A. N. Mariano and R. E. Hanneman, J. Appl. Phys., 34, 384 (1963).

10. W. Jo, S.-J. Kim, and D.-Y. Kim, Acta Mater., 53, 4185 (2005).

11. H. C. Gatos, J. Appl. Phys., 32, 1232 (1961).

12. Q. Zhang, C. S. Dandeneau, X. Zhou, and G. Cao, Adv. Mater. (Weinheim, Ger.), 21, 4087 (2009). 
13. H. Yan, Y. Yang, Z. Fu, B. Yang, L. Xia, S. Fu, and F. Li, Electrochem. Commun., 7, 1117 (2005).

14. Z. Liu, Z. Jin, J, Qiu, X. Liu, W. Wu, and W. Li, Semicond. Sci. Technol., 21, 60 (2006).

15. J. Elias, C. Lévy-Clément, M. Bechelany, J. Michler, G.-Y. Wang, Z. Wang, and L. Philippe, Adv. Mater. (Weinheim, Ger.), 22, 1607 (2010).

16. T. Yoshida, J. Zhang, D. Komatsu, S. Sawatani, H. Minoura, T. Pauporté, D. Lincot, T. Oekermann, D. Schlettwein, H. Tada, D. Wöhrle, K. Funabiki, M. Matsui, H. Miura, and H. Yanagi, Adv. Funct. Mater., 19, 17 (2009).

17. S. Peulon and D. Lincot, J. Electrochem. Soc., 145, 864 (1998).

18. B. Canava and D. Lincot, J. Appl. Electrochem., 30, 711 (2000).

19. A. Goux, T. Pauporté, J. Chivot, and D. Lincot, Electrochim. Acta, 50, 2239 (2005).

20. N. Toyama, R. Hayashi, Y. Sonoda, M. Iwata, Y. Miyamoto, H. Otoshi, K. Saito, and K. Ogawa, Proceedings of 3rd World Conference on Photovoltaic Energy Conversion, 2, 1601 (2003).

21. R. P. Raffaelle, W. Junek, J. Gorse, T. Thompson, J. D. Harris, J. Cowen, D. Hehemann, G. Rybicki, and A. F. Hepp, Mater. Res. Soc. Symp. Proc., 606, 155 (2000).

22. S. O. Klemm, S. E. Pust, A. W. Hassel, J. Hüpkes, and K. J. J. Mayrhofer, J. Solid State Electrochem., In press [DOI: 10.1007/s10008-011-1313-z].

23. M. Berginski, J. Hüpkes, M. Schulte, G. Schöpe, H. Stiebig, B. Rech, and M. Wuttig, J. Appl. Phys., 101, 074903 (2007).

24. T. Roschek, T. Repmann, J. Müller, B. Rech, and H. Wagner, J. Vac. Sci. Technol. A, 20, $492(2002)$.

25. B. Rech, T. Roschek, T. Repmann, J. Müller, R. Schmitz, and W. Appenzeller, Thin Solid Films, 427, 157 (2003).

26. O. Fruhwirth, G. W. Herzog, and J. Poulios, Surf. Technol., 24, 293 (1985).

27. H. Gerischer and N. Sorg, Mater. Corros., 42, 149 (1991). 
28. J. Hüpkes, B. Rech, S. Calnan, O. Kluth, U. Zastrow, H. Siekmann, and M. Wuttig, Thin Solid Films, 502, 286 (2006).

29. Y. C. Lin, Y. C. Jian, and J. H. Jiang, Appl. Surf. Sci., 254, 2671 (2008).

30. M. Pourbaix, Atlas of Electrochemical Equilibria in Aqueous Solutions, p. 411, National Association of Corrosion Engineers, Houston, TX, USA (1974).

31. M. Valtiner, S. Borodin, and G. Grundmeier, Langmuir, 24, 5350 (2008).

32. H. Gerischer and N. Sorg, Electrochim. Acta, 37, 827 (1992).

33. Z. Zembura and L. Burzynska, Corros. Sci., 17, 871 (1977).

34. H. L. Tuller, J. Electroceram., 4, 33 (1999).

35. N. Fujimura, T. Nishihara, S. Goto, J. Xu, and T. Ito, J. Cryst. Growth, 130, 269 (1993).

36. C. Agashe, O. Kluth, J. Hüpkes, U. Zastrow, B. Rech, and M. Wuttig, J. Appl. Phys., 95, 1911 (2004).

37. J. I. Owen, J. Hüpkes, and E. Bunte, Mater. Res. Soc. Symp. Proc., 1153, A07-08 (2009).

38. S. O. Klemm, J.-C. Schauer, B. Schuhmacher, and A. W. Hassel, Electrochim. Acta, 56, 4315 (2011).

39. L. J. van der Pauw, Philips Tech. Rev., 20, 220 (1958/1959). 